\title{
Pendampingan Kelompok Sadar Hukum Dalam Menjalankan Advokasi Hukum Kekerasan Terhadap Perempuan dan Anak di Kabupaten Jember
}

Astutik, Amira Paripurna, Sarwirini, M. Zaidun, Toetik Rahayu, Bambang Suheryadi, Riza Alifianto, Sapta Aprilianto, Prilian Cahyani, Iqbal Felisiano Departemen Hukum Pidana, Fakultas Hukum Universitas Airlangga amira@fh.unair.ac.id

\begin{abstract}
Abstrak
Kelompok sadar hukum dan desa sadar hukum telah dijadikan sebagai salah satu indikator kesadaran hukum masyarakat yang ditetapkan oleh Kementrian Hukum dan HAM RI yang tertuang dalam RENSTRA Kementrian Hukum dan HAM RI. Target dalam program pendampingan kepada masyarakat di Desa Seputih Kecamatan Mayang Jember ini adalah: a. membentuk kelompok sadar hukum; b. kelompok-kelompok sadar yang dibentuk dapat memenuhi kriteria untuk menjadi desa atau kelurahan sadar hukum; c. Kelompok sadar hukum yang dibentuk melakukan advokasi terhadap permasalahan hukum (terutama kasus kekerasan perempuan anak dan penyalahgunaan obat-obatan terlarang, korupsi) yang terjadi di lingkungannya. Metode dan tahapan pelaksanaan kegiatan adalah melalui: a. kegiatan temu sadar hukum (ceramah, simulasi); b. diseminasi buku panduan (buku saku) 'melek hukum'; c. pendampingan pembentukan kelompok sadar hukum; d. Pendampingan aktivitas advokasi oleh kelompok sadar hukum. Luaran kegiatan ini adalah terbentuknya dan berdirinya 1 (satu) kelompok sadar hukum dan kelompok advokasi di kecamatan Mayang; Pendampingan aktivitas advokasi yang dilakukan oleh kelompok sadar hukum
\end{abstract}

Kata kunci : advokasi, desa, hukum,kekerasan, perempuan.

\begin{abstract}
The establishment of law community in the village level is one of indicator of legal awareness in society. This indicator has been set up through national strategic planning of the Indonesian Ministry of Legal affairs and Human Rights. The community service conducted by Criminal Law Department aims to encourage and advocate the community in Seputih Village to establish a law community. Through the establishment of law community in Seputih Village, the community will be able to independently resolve and conduct advocacy to the community issues, in particularly the issue of violence against women and children.
\end{abstract}

Keywords: advocacy, children, law, violence, village, women.

\section{PENDAHULUAN}

Perkembangan teknologi dan informasi saat ini memang telah membuat masyarakat semakin mudah untuk mendapatkan berita terkait dengan tindakan perbuatan pelanggaran hukum yang terjadi di dalam masyarakat misalnya terkait dengan tindakan pencurian, 
narkoba, asusila, kekerasan, tawuran pelajar, bentrokan antar warga di beberapa daerah, perebutan lahan pertanian, tambang, judi, korupsi dll. Hal ini membutuhkan pemahaman masyarakat terhadap hukum. Masyarakat membutuhkan pengetahuan lebih cepat terhadap perkembangan hukum dan penyelesaian terhadap permasalahan hukum yang terjadi dalam lingkungan kehidupan sosialnya.

Karena itu, dalam rangka mewujudkan visi pemerintahan yang digariskan dalam dokumen Nawacita, pemerintah pusat, dalam hal ini Kementrian Hukum dan HAM dengan Kementrian Desa, Pembangunan Daerah Tertinggal dan Transmigrasi melakukan sinergi terkait program terhadap desa, untuk membangun kesadaran hukum masyarakat, membina dan membentuk kelompok/keluarga dan desa sadar hukum dan memberi akses bantuan hukum kepada orang miskin atau kelompok miskin. ${ }^{1}$ Pembangunan kesadaran hukum masyarakat merupakan kegiatan yang ditujukan untuk meningkatkan abstraksi mengenai peranan hukum dari subyek hukum yang berkaitan dengan nilai-nilai konsepsi dalam diri manusia mengenai keserasian antara ketertiban dan ketentraman yang dikehendaki. ${ }^{2}$

Desa atau kelurahan sebagai organisasi pemerintah paling rendah, memiliki makna strategis untuk menjadi sasaran pembinaan. Hal ini disebabkan Desa/Kelurahan berhubungan langsung dengan rakyat sekaligus dapat menjadi ruang bersama untuk hidup dengan aturan hukum maupun sebagai Lembaga administrasi yang memberi pelayanan publik, merupakan lingkungan sosial pertama dimana rakyat saling berinteraksi dengan adat maupun hukum formal. Menjadikan desa/kelurahan sebagai sasaran dan sarana pembinaan yang utama memberikan efek berlipat. Kelompok sadar hukum dan desa sadar hukum ini dijadikan indikator kesadaran hukum masyarakat yang ditetapkan oleh Kementrian Hukum dan HAM RI yang tertuang dalam RENSTRA Kementrian Hukum dan HAM RI. Sampai pada triwulan pertama tahun 2011, Indonesia baru memiliki 2838 kelompok sadar hukum dan 969 desa sadar hukum, atau baru sekitar l persen dari jumlah desa di seluruh Indonesia (BPHN 2011). Tentu angka ini akan terus bertambah mengingat program pembinaan kelompok kadarkum dan desa sadar hukum terus digalakkan oleh Pusat Penyuluhan Hukum Badan Pembinaan Hukum Nasional, melalui kantor wilayahkantor wilayah Kementrian Hukum dan HAM di seluruh Indonesia.

Indikator kesadaran hukum terdiri dari beberapa aspek, diantaranya: pengetahuan tentang peraturan hukum, sikap terhadap peraturan hukum dan pola perilaku hukum. Sementara itu, peningkatan kesadaran hukum masyarakat dilakukan dengan meningkatkan

\footnotetext{
Pada awal tahun 2016 telah diterbitkan Nota Kesepakatan antara Menteri Hukum dan HAM dengan Menteri Desa, Pembangunan Daerah Tertinggal dan Transmigrasi Nomor: M.HH-05.HM.05.02 Tahun 2016 dan NomoroL 01/M-DPDTT/KB/I/2016 Tahun 2016 tentang Pembentukan dan Pembinaan Keluarga Sadar Hukum dalam rangka Mewujudkan Desa Sadar Hukum dan Akses Pemberian Bantuan Hukum kepada Orang Miskin atau Kelompok Miskin.

2 Berdasarkan Peraturan Presiden No.5 Tahun 2010 tentang Rencana Pembangunan Jangka Menengah, pemerintah telah menetapkan arah kebijakan untuk memperbaiki substansi (materi) hukum, struktur (kelembagaan) hukum, dan culture (budaya hukum) melalui berbagai upaya.
} 
akses terhadap segala informasi yang dibutuhkan oleh masyarakat untuk terlibat dalam berbagai proses pengambilan keputusan dalam pelaksanaan pembangunan nasional. Dengan demikian, setiap anggota masyarakat menyadari dan menghayati hak dan kewajiban sebagai warga negara. Peningkatan kesadaran hukum masyarakat tersebut harus didukung dengan pelayanan yang baik, dengan biaya yang terjangkau, proses yang tidak berbelit dan mencerminkan rasa keadilan.

Mencermati fenomena yang berkembang selama beberapa tahun terakhir dan berdasarkan hasil penelitian untuk menetapkan Kelompok Sadar Hukum dan Desa Sadar Hukum, minimum diperlukan 7 (Tujuh) kriteria sebagai berikut (Badan Penelitian dan Pengembangan Hukum dan HAM, 2016):

1. Angka kriminalitas rendah termasuk semua jenis kejahatan yang diatur dalam KUHP

2. Rendahnya kasus narkoba;

3. Tingginya kesadaran masyarakat terhadap kebersihan dan kelestarian lingkungan;

4. Kekerasan dalam rumah tangga;

5. Korupsi;

6. Tingkat Pendidikan Masyarakat Minimal SMA;

7. Kriteria lain yang ditetapkan daerah.

Selain itu masih lemahnya kesadaran masyarakat terhadap peraturan dan produk hukum daerah, salah satu penyebabnya adalah karena akses terhadap sumber-sumber hukum yang ada selama ini masih sangat terbatas. Hal ini terutama dialami oleh masyarakat yang berada di daerah pinggiran. Akibat dari ketidaktahuan terhadap hukum, masyarakat menjadi ladang bagi orang-orang yang tidak bertanggung jawab untuk mengeruk keuntungan pribadi. Maka dari itu sangat penting untuk turut berpartisipasi aktif untuk mendorong terciptanya kelompok-kelompok masyarakat yang melek dan sadar hukum. Selain itu, partisipasi aktif ini merupakan salah satu upaya percepatan menuju desa mandiri dan berdaulat, yakni membangun sumber daya manusia yang berbudaya hukum.

\section{METODE}

Berdasarkan Peraturan Menteri Hukum dan HAM RI No : M.01-Pr.08.10 Tahun 2006 Tentang Pola Penyuluhan Hukum disebutkan tentang metode-metode penyuluhan hukum bagi warga masyarakat. Metode-metode tersebut terdiri dari penyuluhan hukum langsung dan penyuluhan hukum tidak langsung. Penyuluhan hukum langsung dilakukan dengan cara bertatap muka secara langsung antara penyuluh dan yang disuluh, sementara penyuluhan hukum tidak langsung dilakukan melalui media elektronik dan media cetak. Mengacu kepada peraturan tersebut, pengabdian masyarakat ini dilakukan dengan cara penyuluhan hukum langsung. Adapun metode pelaksanaan kegiatan yang akan dilaksanakan dalam kegiatan pengabdian ini akan terbagi menjadi 4 tahapan : 
a. Kegiatan temu sadar hukum melalui ceramah/temu dan dialog hukum. Kegiatan ini berupa pertemuan berkala antara para anggota dalam satu Kadarkum atau antara Kadarkum yang satu dengan Kadarkum lainnya atau antara Kadarkum yang satu dengan kelompok lain yang ada dalam masyarakat, dengan melakukan kegiatan yang dapat meningkatkan kesadaran hukum bagi mereka;

b. Diseminasi buku panduan (buku saku) 'melek hukum';

d. Pendampingan pembentukan kelompok sadar hukum

e. Pendampingan advokasi mandiri,

Kegiatan Pengabdian kepada Masyarakat dilaksanakan selama 6 (Enam) bulan.

\section{HASIL DAN PEMBAHASAN}

Kadarkum dibentuk oleh anggota masyarakat yang dengan kemauannya sendiri berusaha untuk meningkat kesadaran dan pengetahuan hukum bagi dirinya. Tujuan dari pembinaan Kadarkum adalah terwujudnya kesadaran hukum masyarakat. Kesadaran hukum merupakan keluaran (out-put) dari proses kegiatan penyuluhan dan pembinaan yang mencapai tingkat optimalisasi ideal yang ditandai dengan timbulnya rasa untuk menghargai hukum. Dengan dipahaminya hukum, kesadaran hukum masyarakat diharapkan meningkat menjadi menghargai hukum. Tahap memahami hukum menjadi menghargai hukum dapat terjadi apabila dalam proses memahami tersebut warga masyarakat menghayati tentang adanya manfaat hukum bagi kehidupan bersama di dalam masyarakat bersangkutan, dan hal ini bila warga masyarakat tersebut mengetahui tujuan dan tugas hukum yang sesungguhnya diperlukan. Selain itu penyalahgunaan Narkoba dan KDRT dapat terjadi pada siapa saja, tanpa melihat perbedaan status sosial, ekonomi dan usia.

Berdasarkan survei Kementerian Desa Tertinggal di Kabupaten Jember terdapat 1 desa yang sangat tertinggal, 46 desa tertinggal, 114 desa berkembang, dan 60 desa maju. Hal ini menunjukan bahwa Kabupaten Jember memiliki potensi yang tinggi untuk terus melakukan percepatan untuk meningkatkan kualitas pembangunan sumber daya manusianya melalui pendampingan-pendampingan terhadap desa-desa yang sangat tertinggal, tertinggal dan berkembang, sehingga diharapkan secara keseluruhan nantinya dapat masuk dalam kriteria desa maju.

Kegiatan awal pengabdian maasyarakat di kecamatan Mayang, desa Seputih dilakukan pada bulan Juli 2018. Kegiatan dihadiri oleh sebanyak 67 warga masyarakat yang ditempatkan di balai desa 'Desa Seputih'. Adapun warga masyarakat yang hadir merupakan representatif dari Kelompok Karang Taruna, Perangkat Desa, Kelompok kader ibu-ibu PKK dan Pengajian. Kegiatan lanjutan dilakukan pada temu hukum sebanyak 6 (Juli-Desember 
2018) dikelompok pengajian perempuan dengan jumlah peserta 60 orang di Desa Seputih, Kecamatan Mayang.

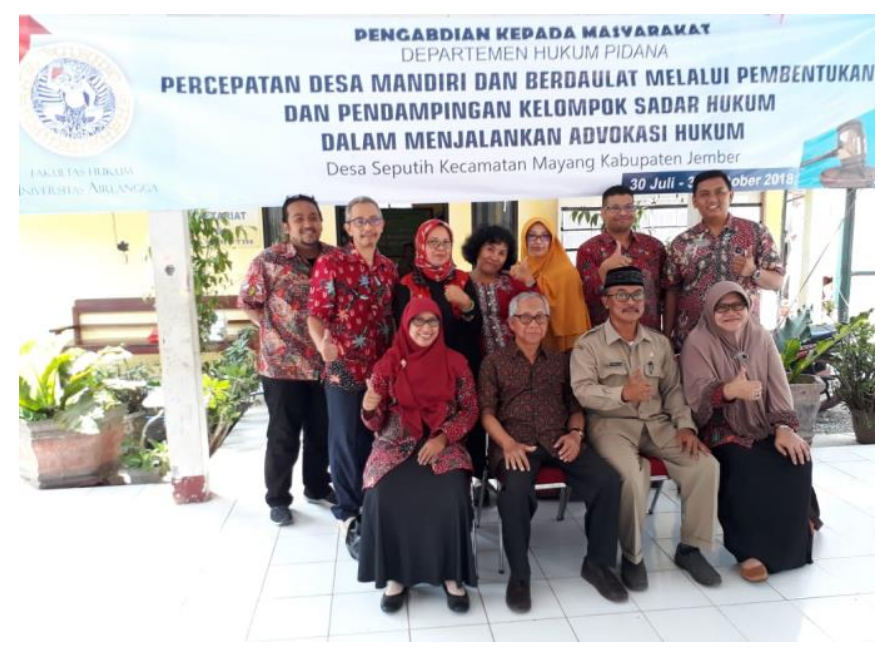

Gambar 1: Tim Pengmas Departemen Hukum Pidana, mengawali kegiatan pengabdian untuk membentuk Kelompok Sadar Hukum di Desa Seputih, Kecamatan Mayang, Kabupaten Jember, pada Bulan Juli 2018.

Dalam kegiatan awal tersebut, disampaikan sejumlah materi dasar pembuka wawasan bagi warga yang hadir. Sejumlah materi dasar tersebut diantaranya mengenai Pencegahan dan penyalahgunaan Narkoba, Korupsi, lingkungan dan Penghapusan Kekerasan Dalam Rumah Tangga, merupakan isu hukum yang menyentuh secara langsung kepada kepentingan masyarakat, dan diharapkan agar Kader Kadarkum menyebarluaskan kembali materi pembuka wawasan tersebut kepada masyarakat.

Hasil dari sinergi tim Pengmas Departemen Hukum Pidana dan Warga Desa Seputih, Kecamatan Mayang, kini telah berhasil mewujudkan terbentuknya satu kelompok sadar hukum yang terbentuk pada Desember 2018. Anggota kelompok sadar hukum Desa Mayang ini sebagian besar adalah berasal dari kelompok pengajian Jum'at-Malam yang terdiri dari sekitar 50 orang. Dari 50 orang tersebut terdapat 15 orang yang berpotensi dan bersedia untuk menjadi kader dan anggota kelompok sadar hukum. Sebagian besar adalah perempuan dan berprofesi sebagai guru, ibu rumah tangga, petani dan buruh. Sedangkan tingkat pendidikan bervariasi dari level D3, SMA hingga SMP. 


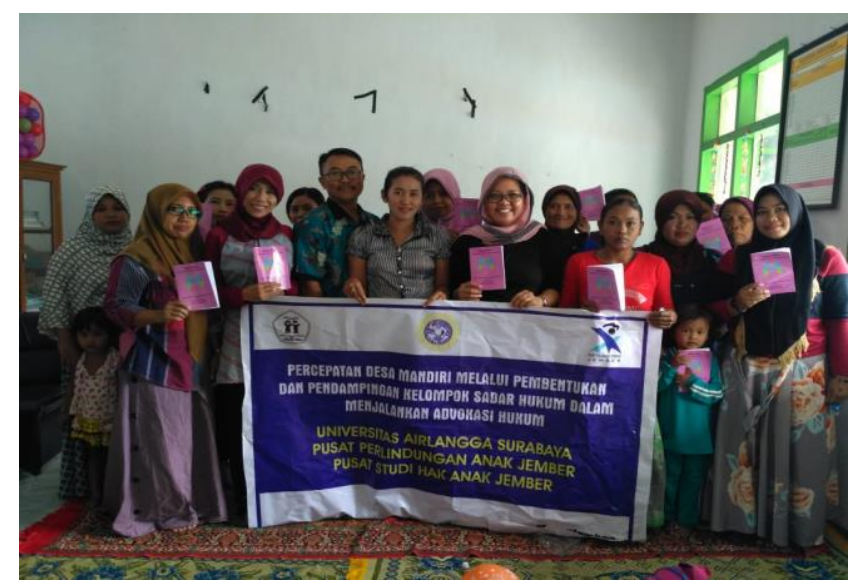

Gambar 2: Kelompok Sadar Hukum Desa Mayang

Pada saat diadakan serangkaian "temu hukum" antara Tim Pengabdian Masyarakat Departemen Hukum Pidana, Fakultas Hukum, Universitas Airlangga, hampir kesuluruhan anggota yang hadir antusias dalam melakukan sharing terkait permasalahan hukum dilingkungannya terutama terkait dengan isu kekerasan terhadap perempuan dan anak. Dalam temu hukum yang dilakukan oleh Tim Pengmas Departemen Pidana Fakultas Hukum Universitas Airlangga, para kader telah dibekali pengetahuan-pengetahuan terkait dengan perundang-undangan tentang perlindungan hukum bagi perempuan dan anak korban kekerasan. Bahkan, dalam kurun waktu satu minggu paska pembentukan kelompok sadar hukum Desa Mayang ini, telah menerima sejumlah pengaduan dari warga mengenai kasus kekerasan dalam rumah tangga yang dialami oleh warga sekitar yang berada di Desa Mayang.

Dalam kegiatan pengabdian Masyarakat ini selanjutnya tim departemen hukum pidana bekerja sama dengan Pusat Pelayanan Terpadu (PPT) dan Pusat Studi Hak Anak (PSHA) Kabupaten Jember. Serangkaian 'temu dan dialog hukum' dengan sejumlah tema, yaitu Pemetaan masalah isu kekerasan terhadap perempuan dan anak di kelompok sasaran, "Forum Diskusi" terhadap hasil pemetaan masalah, Alur pelayanan terhadap korban kekerasan terhadap perempuan dan anak, serta Aspek hukum dan sosial masalah kekerasan terhadap perempuan dan anak 


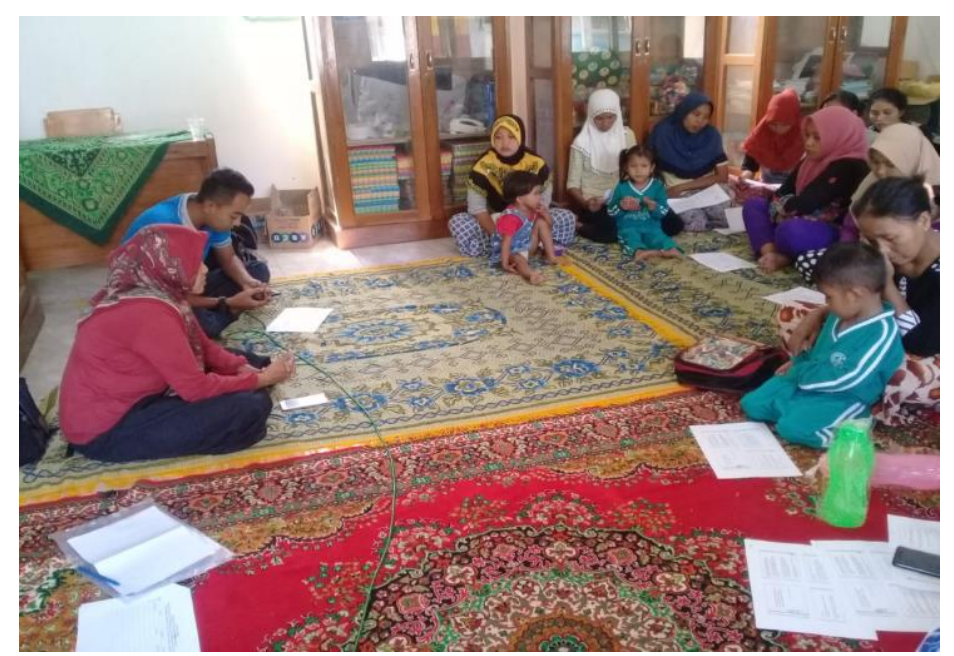

Gambar 3: Temu dan Dialog Hukum bersama Tim dari Pusat Pelayanan Terpadu (PPT) dan Pusat Studi Hak Anak (PSIHA) Kabupaten Jember dengan tema Alur Layanan dan Penanganan Korban Kekerasan Terhadap Perempuan dan Anak

Dari hasil 'temu hukum' tergali sejumlah peluang dan kesempatan mengembangkan kelompok sadar hukum dilihat dari antusiasme para anggota/kader-kader yang masih baru menjadi anggota kelompok sadar hukum Desa Seputih. Namun kendala dan permasalahan yang dihadapi para kader adalah kurangnya kapasitas dan ketrampilan para anggota dalam memberikan konseling dasar bagi perempuan dan anak yang menjadi korban kekerasan. Selain itu juga para kader memiliki pengetahuan yang minim dalam melakukan advokasi kasus kekerasan dalam rumah tangga, serta bentuk-bentuk kekerasan terhadap perempuan dan anak.

Teknik konseling bersprektif korban dan berkeadilan gender serta teknik dasar-dasar advokasi menjadi kebutuhan dasar bagi para kader di kelompok sadar hukum untuk dapat melaksanakan advokasi hukum secara berkelanjutan dan berkesinambungan. Dengan kegiatan peningkatan kapasitas terhadap kader kelompok sadar hukum ini diharapkan dapat melakukan advokasi secara tepat, efisien dan sesuai dengan prinsip-prinsip yang berpresprektif korban serta berkeadilan gender.

\section{KESIMPULAN}

Pembentukan kelompok sadar hukum di Desa Mayang merupakan salah satu sarana untuk mengembangkan masyarakat desa menuju masyarakat Madani dan berdaya dan mandiri. Mandiri terutama dalam kemampuan berkehendak menjalankan inisiatif lokal dalam mengahadapi permasalahan hukum dilingkungan sekitarnya, terutama terkait dengan permasalahan-permasalahan kekerasan terhadap perempuan dan anak. Pembentukan 
kelompok sadar hukum ini telah memberikan kontribusi terhadap upaya pemenuhan kesetaraan dan keadilan gender melalui ketersediaan wadah kegiatan 'pos' pelayanan pengaduan dan bantuan advokasi kasus kekerasan terhadap perempuan dan anak didesa.

Diperlukan kegiatan penguatan kapasitas bagi anggota kelompok sadar hukum untuk dapat melaksanakan advokasi hukum secara berkelanjutan dan berkesinambungan. Kegiatan penguatan kapasitas yang dapat dilakukan misalnya berupa teknik konseling bersprektif korban dan berkeadilan gender serta teknik dasar-dasar advokasi menjadi kebutuhan dasar bagi para kader di kelompok sadar hukum. Dengan kegiatan peningkatan kapasitas terhadap kader kelompok sadar hukum ini diharapkan dapat melakukan advokasi secara tepat, efisien dan sesuai dengan prinsip-prinsip yang berpresprektif korban serta berkeadilan gender.

\section{DAFTAR PUSTAKA}

Badan Penelitian dan Pengembangan Hukum dan HAM. 2016. Penentuan Kriteria Desa/Kelurahan Sadar Hukum. Jakarta: KemenhumHAM RI

Soerjono Soekanto. 1997. Beberapa Cara dan Mekanisme dalam Penyuluhan Hukum. Jakarta. Pradnya Paramita.

Nugroho Riant. 2010. Public Policy: Teori dan Metode. Jakarta: Gramedia

Ahmad Suhendi, Model Desa Berketahanan Sosial dalam Pembangunan Kesejahteraan Sosial. Informasi Vol 16 No. 1 (2011).

Nevey Varida Ariani. Relevansi Penentuan Kriteria Desa/Kelurahan Sadar Hukum Terhadap Kesadaran Hukum Masyarakat. Jurnal Penelitian Hukum DE JURE, ISSN 1410-5632 Vol. 17 No. 1, (2017). 